\title{
$11 \beta$-Hydroxysteroid Dehydrogenase Type 1 Expression Is Increased in the Aged Mouse Hippocampus and Parietal Cortex and Causes Memory Impairments
}

\author{
Megan C. Holmes, ${ }^{1,3}$ Roderick N. Carter, ${ }^{1}$ June Noble, ${ }^{1}$ Shruti Chitnis, ${ }^{1}$ Amy Dutia, ${ }^{1}$ Janice M. Paterson, ${ }^{2}$ \\ John J. Mullins, ${ }^{2}$ Jonathan R. Seckl, ${ }^{1,3}$ and Joyce L. W. Yau ${ }^{1,3}$ \\ ${ }^{1}$ Endocrinology Unit and ${ }^{2}$ Molecular Physiology Group, Centre for Cardiovascular Science and ${ }^{3}$ Centre for Cognitive Ageing and Cognitive Epidemiology, \\ University of Edinburgh, University of Edinburgh, Queen's Medical Research Institute, Edinburgh EH16 4TJ, United Kingdom
}

Increased neuronal glucocorticoid exposure may underlie interindividual variation in cognitive function with aging in rodents and humans. $11 \beta$-Hydroxysteroid dehydrogenase type 1 (11 $\beta$-HSD1) catalyzes the regeneration of active glucocorticoids within cells (in brain and other tissues), thus amplifying steroid action. We examined whether $11 \beta$-HSD1 plays a role in the pathogenesis of cognitive deficits associated with aging in male $\mathrm{C} 57 \mathrm{BL} / 6 \mathrm{~J}$ mice. We show that $11 \beta$-HSD1 levels increase with age in CA3 hippocampus and parietal cortex, correlating with impaired cognitive performance in the water maze. In contrast, neither circulating corticosterone levels nor tissue corticosteroid receptor expression correlates with cognition. $11 \beta$-HSD1 elevation appears causal, since aging (18 months) male transgenic mice with forebrain-specific $11 \beta$-HSD1 overexpression ( $~ 50 \%$ in hippocampus) exhibit premature age-associated cognitive decline in the absence of altered circulating glucocorticoid levels or other behavioral (affective) deficits. Thus, excess $11 \beta$-HSD1 in forebrain is a cause of as well as a therapeutic target in memory impairments with aging.

\section{Introduction}

Chronically elevated glucocorticoid (GC) levels are detrimental to the brain, especially to the hippocampus. In the adult hippocampus, GC excess potentiates excitatory neurotransmission, disrupts electrophysiological functions such as long-term potentiation (LTP) thought to underlie memory, interferes with learning and recall, promotes dendritic atrophy, and may potentiate neurotoxicity (McEwen et al., 1999). Interindividual differences in plasma GC levels may underpin variation in cognitive function with aging (Meaney et al., 1995) and higher steroid levels associating with and even predicting subsequent cognitive deficits and hippocampal atrophy in rodents (Yau et al., 2002) and humans (Lupien et al., 1998). Elevated GC levels appear causal of cognitive decline with aging, since manipulations that maintain low GC levels from mid-life, such as adrenalectomy and low-dose GC replacement (Landfield et al., 1981) and antidepressant drug therapy (Yau et al., 2002), prevent the emergence of cognitive deficits with subsequent aging, at least in rodents.

GC action on target cells is not dependent merely upon hormone levels in the circulation and the density of intracellular

\footnotetext{
Received Feb. 10, 2010; revised March 24, 2010; accepted April 2, 2010.

This work was supported by a Wellcome Trust project grant (WT070207; M.C.H., J.L.P., J.J.M., J.R.S.), a Medical Research Council project grant (G0501596; J.L.W.Y., J.R.S.), and a Wellcome Trust program grant (WT083184; J.R.S., J.J.M.). J.L.W.Y. holds a Research Councils UK Academic Fellowship. M.C.H., J.L.W.Y., and J.R.S. are members of The University of Edinburgh Centre for Cognitive Aging and Cognitive Epidemiology, part of the cross council Lifelong Health and Wellbeing Initiative (G0700704/84698). Funding from the Biotechnology and Biological Sciences Research Council, Engineering and Physical Sciences Research Council, Economic and Social Research Council, and Medical Research Council is gratefully acknowledged.

Correspondence should be addressed to Prof. Jonathan R. Seckl, Queen's Medical Research Institute, 47 Little France Crescent, Edinburgh EH16 4TJ, UK. E-mail: J.Seckl@ed.ac.uk.

D0I:10.1523/JNEUROSCI.0731-10.2010

Copyright $\odot 2010$ the authors $\quad 0270-6474 / 10 / 306916-05 \$ 15.00 / 0$
}

glucocorticoid (GR) and mineralocorticoid (MR) receptors in target tissues, but also on prereceptor metabolism by $11 \beta$ hydroxysteroid dehydrogenases (11 $\beta$-HSDs) (Holmes and Seckl, 2006). The adult rodent and human brains highly express only the type 1 isozyme ( $11 \beta$-HSD1), which catalyzes the regeneration of active glucocorticoids (cortisol, corticosterone) from inert 11keto forms (cortisone, 11-dehydrocorticosterone) in neurons (Rajan et al., 1996), thus amplifying cellular GC action. Importantly, aged mice deficient in $11 \beta$-HSD1 $\left(11 \beta\right.$-HSD $1^{-/-}$mice) have reduced intrahippocampal levels of corticosterone despite normal circulating concentrations (Yau et al., 2001). 11 $\beta$ HSD $1^{-1-}$ mice are protected from the normal decline in memory and hippocampal LTP seen with aging (Yau et al., 2001, 2007 ), suggesting that $11 \beta$-HSD1 is an important control of intraneuronal GC action in vivo. Hence, $11 \beta$-HSD1 inhibition is a target for therapy of age-associated cognitive disorders (Wamil and Seckl, 2007). Indeed, in two small randomized, double-blind, placebo-controlled trials, an $11 \beta$-HSD inhibitor improved cognitive function in elderly men and patients with type 2 diabetes (Sandeep et al., 2004). However, these genetic and therapeutic manipulations affect the whole body, and $11 \beta$-HSD 1 is highly expressed in peripheral organs, notably in liver and adipose tissue (Stewart et al., 1999). The primary role of $11 \beta$-HSD1 in the brain per se is not clear cut. For example, changes in peripheral (hepatic) $11 \beta$-HSD1 alone alter brain function, at least at the level of the hypothalamic-pituitary-adrenal (HPA) axis (Paterson et al., 2007).

While $11 \beta$-HSD1 is elevated selectively in adipose tissue in human and rodent obesity (Livingstone et al., 2000; Rask et al., 2002) and appears a plausible cause of metabolic syndrome 

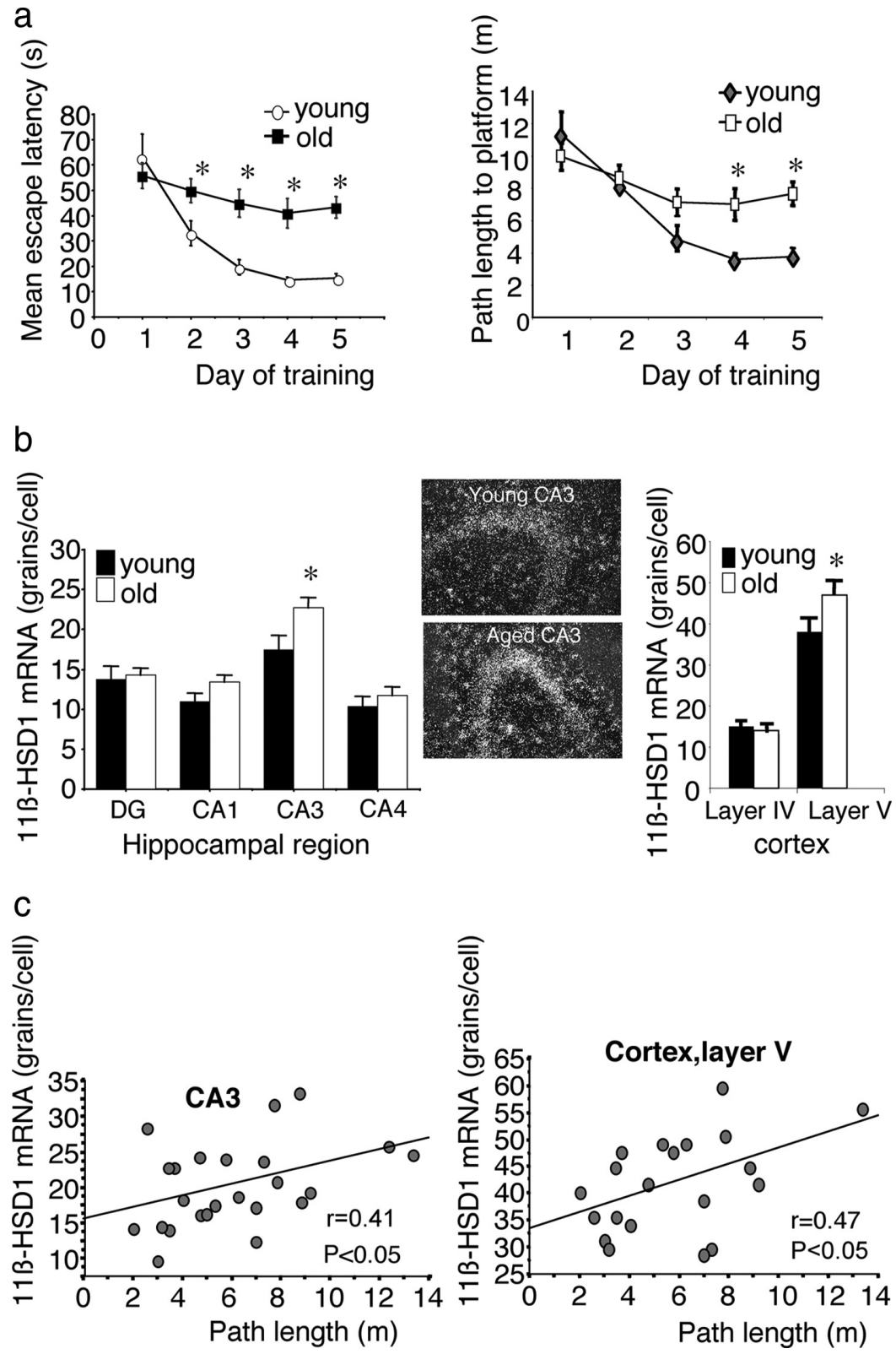

Figure 1. Cognitively impaired aged mice have increased $11 \beta$-HSD1 mRNA in hippocampus and cortex. a, Aged $24-27$ month C57BL/6J mice $(n=14)$ show impaired spatial learning in the water maze [escape latency and path length (mean \pm SEM) to find submerged platform]; ${ }^{*} p<0.001$, compared with young 6 m controls $(n=10)$. $\boldsymbol{b}$, Aged mice have increased $11 \beta$-HSD1 mRNA in CA3 hippocampal and cortical layer V cells; ${ }^{*} p<0.05$ compared with young. c, $11 \beta$-HSD1 mRNA expression in CA3 hippocampus and layer $V$ cortex correlates $(p<0.05)$, with mean path length (day 5$)$ to find the hidden platform.

formed in strict accordance with the United Kingdom Animals (Scientific Procedures) Act (1986).

Basal $(0800 \mathrm{~h})$ tail venesection blood samples were taken for corticosterone assay. At least 1 week later, animals were tested in the reference memory water maze task, first learning to escape to a visible platform (submerged but marked with visible tower block protruding $10 \mathrm{~cm}$ on top) over four consecutive days of nonspatial training (three trials per day with curtains around the pool to hide visuospatial cues) and then a hidden platform over five consecutive days of spatial training (four trials per day with no curtains), essentially as described by Yau et al. (2007). One hour after the last spatial training trial, a 60 s probe trial was performed with the platform removed. Swim paths and measures of performance were analyzed by WaterMaze software (Actimetrics). Aged mice showing signs of motor or visual impairments were excluded ( 2 aged mice were excluded of 16 tested). Mice were killed by decapitation and the brains were removed and snap-frozen on soft dry ice for cryostat sectioning and in situ hybridization using ${ }^{35} \mathrm{~S}$-UTPlabeled cRNA antisense probes as described (Mattsson et al., 2003) for $11 \beta$-HSD1, MR, and GR mRNAs in the anterior hippocampus. Slides were dipped in photographic emulsion (NTB-2, Kodak) and exposed at $4^{\circ} \mathrm{C}$ for $14-21 \mathrm{~d}$.

\section{Transgenic mice with forebrain} overexpression of $11 \beta-H S D 1$

Generation of construct for forebrain overexpression of $11 \beta-H S D 1$ and preparation of DNA fragment for mouse embryo microinjection. The rat $11 \beta$-HSD1 cDNA-based minigene, previously used to overexpress $11 \beta$-HSD1 in adipose tissue and liver (Masuzaki et al., 2001; Paterson et al., 2004), was fused in-frame at the $\mathrm{C}$ terminus to the influenza virus-derived hemagglutinin (HA) epitope tag by PCR-mediated, site-directed mutagenesis. This was inserted downstream of the CamIIK promoter directing transgene expression to the forebrain to yield CamIIK-HSD1, a $10.5 \mathrm{~kb}$ DNA fragment, was prepared for microinjection by agarose gel electrophoresis, electroelution, and dialysis against $10 \mathrm{~mm}$ Tris.HCl/0.1 mM EDTA (pH7.4) before dilution of DNA to a concentration of $1 \mathrm{ng} / \mu \mathrm{l}$. Construct expression was confirmed by transfection into Cos7 cells, and $11 \beta$-HSD1 activity was measured.

Generation of transgenic animals and geno-

(Masuzaki et al., 2001, 2003), any primary role of $11 \beta$-HSD1 in the CNS in causation of cognitive variation with aging is unexplored. Here, we examined the critical issues of whether endogenous $11 \beta$-HSD1 levels vary with cognitive function in the hippocampus of aged mice, and whether specific elevation of $11 \beta$-HSD 1 in the forebrain (including the hippocampus) has cognitive consequences with aging.

\section{Materials and Methods}

\section{Control C57BL/6J mice}

Male C57BL/6J mice were purchased at 8-10 weeks old (Harlan) and maintained in cages housing 3-4 mice on standard chow (product 801190, Special Diet Services) and tap water ad libitum (lights on $0700-$ 1900 ) in our animal facilities until they were ready for experimentation at 6 months (young) and 24-27 months (aged). All procedures were per- typing of experimental animals. Microinjection into the pronuclei of fertilized C57BL/ $6 \times \mathrm{CBA} / \mathrm{C} 3 \mathrm{H}$ F1 embryos was performed using standard techniques. $G_{0}$ offspring were screened by Southern blot hybridization analysis of tail biopsy genomic DNA digested with BamHI and probed with $\left[\alpha-{ }^{32} \mathrm{P}\right] \mathrm{dCTP}$-labeled rat $11 \beta$-HSD 1 cDNA to reveal diagnostic restriction fragments. Transgenic lines 3615 and 3621 carrying high and low copies of the transgene, respectively, were propagated from independent founder animals. F7 or greater C57BL/6J backcross male mice were studied throughout. Mice hemizygous for the transgene [referred to as CamIIK-HSD1 or transgenic (Tg) mice] were compared with nontransgenic [wild-type (wt)] littermate controls. Animals were fed standard chow and water ad libitum.

Localization and expression of the $11 \beta$-HSD1 transgene. The expression pattern of the transgene was determined by immunohistochemistry, using an antibody directed against the HA tag. Mice (terminally anesthe- 
tized with sodium pentabarbitone) were transcardially perfused with $4 \%$ paraformaldehyde, and the brains were postfixed and frozen. Transgene protein was localized on $60 \mu \mathrm{M}$ coronal cryostat sections using a rabbit anti-HA antibody (catalog \#71-5500, Invitrogen, Zymed Laboratories) in conjunction with the streptavidin-biotin-based peroxidase staining system (Vector Laboratories). Controls included wild-type littermates. To determine the effect of the transgene on $11 \beta$-HSD1 activity, various brain regions were homogenized and assayed as described (Sandeep et al., 2004). After this basic characterization, studies focused on the highest expressing line (3615), which exhibited hippocampal $11 \beta$ HSD 1 activity $50 \%$ above that of wild type. Key data were confirmed in a separate line (3621).

HPA axis function. Male CamIIK-HSD1 Tg mice and their wt littermates aged 3-6 months were housed singly for 1 week before study. Basal blood samples were taken by tail nick at $0800-0900 \mathrm{~h}$ for circadian nadir and 1900-2000 h for peak corticosterone levels. At least 1 week later, animals were subjected to restraint stress (10 $\mathrm{min})$, with samples taken before and 10 and $90 \mathrm{~min}$ after stress. Plasma corticosterone was determined by radioimmunoassay as described previously (Paterson et al., 2007).

Behavior. Male Tg mice and wild-type mice, young (6-9 months) and aged (18 months), were accustomed to the behavioral room to minimize stress. Mice were tested for affective behaviors in the open field and elevated plus maze (Holmes et al., 2006) and for learning and spatial memory retention (probe test) in the water maze as described above for C57BL/6J mice. Data were accumulated by automated video recording and quantified blind to genotype. In addition, conditioned passive avoidance was assessed in a light/dark box (step-through passive avoidance apparatus; Ugo Basile) using the following protocol: day 1: $5 \mathrm{~min}$ free exploration of the apparatus; day 2: latency to enter the dark compartment, followed by a mild $0.3 \mathrm{~mA}$ or moderate $0.5 \mathrm{~mA} 3 \mathrm{~s}$ footshock in the dark compartment, then retest $5 \mathrm{~h}$ later for latency to enter the dark compartment. Latencies are measured automatically by the integral software following the opening of the door separating the light and dark components. Old (18 months) mice (wt or $\mathrm{Tg}$ ) failed to respond to the same magnitude of shock $(0.3 \mathrm{~mA})$ as young mice with an increased latency to re-enter the dark compartment, suggesting insensitivity to mild shock, and they were thus given a more intense footshock $(0.5 \mathrm{~mA})$.

\section{Statistics}

Differences by genotype were analyzed by Student's $t$ test or one- or two-way ANOVA with post hoc Tukey's honestly significant difference tests, as appropriate. Significance was set at $p<0.05$. Data are means \pm SEMs.

\section{Results}

Young ( 6 months, $n=10)$ and aged (24-27 months, $n=14$ ) male C57BL/6J mice were tested in the reference memory water maze task (Fig. 1a). Aged mice had slower average swim speeds (young $0.25 \pm 0.01 \mathrm{~m} / \mathrm{s}$; old $0.18 \pm 0.01 \mathrm{~m} / \mathrm{s}$; ANOVA, age effect, $\left.F_{(1,22)}=17.9, p=0.0003\right)$ but showed similar visible platform learning over $4 \mathrm{~d}$ of trials (decrease in escape latency: young, $18.58 \pm 1.20 \mathrm{~s}$; old, $\left.21.84 \pm 3.44 \mathrm{~s} ; F_{(1,22)}=0.6, p=0.4\right)$, indicating no difference in perception (vision) or motivation with aging. While young mice were able to acquire the spatial memory task with $5 \mathrm{~d}$ of training, aged mice were impaired in their spatial learning performance [escape latency, ANOVA, age effect: $F_{(1,22)}=$ $14.8, p=0.0009$; path length: $F_{(1,22)}=4.2, p=0.05$ ], failing to acquire the task as confirmed in the probe trial [percentage time in target quadrant of probe test: young $47.46 \pm 2.77$; aged $25.4 \pm 2.7$; ANOVA, age effect: $F_{(1,22)}=30.8, p<0.001$ ] (Fig. $1 a$ ).

Hippocampal $11 \beta$-HSD1 mRNA levels were significantly increased with aging selectively in CA3 pyramidal cells $\left(F_{(1,22)}=5.6\right.$, $p<0.05$ ) (Fig. 1b). Examination of individual animals revealed that $11 \beta$-HSD1 mRNA in CA3 cells correlated with spatial learning and spatial memory retention [path length to platform on day 5: $r=0.41, F_{(1,22)}=4.3, p<0.05$; probe test: $r=0.44, F_{(1,22)}=$
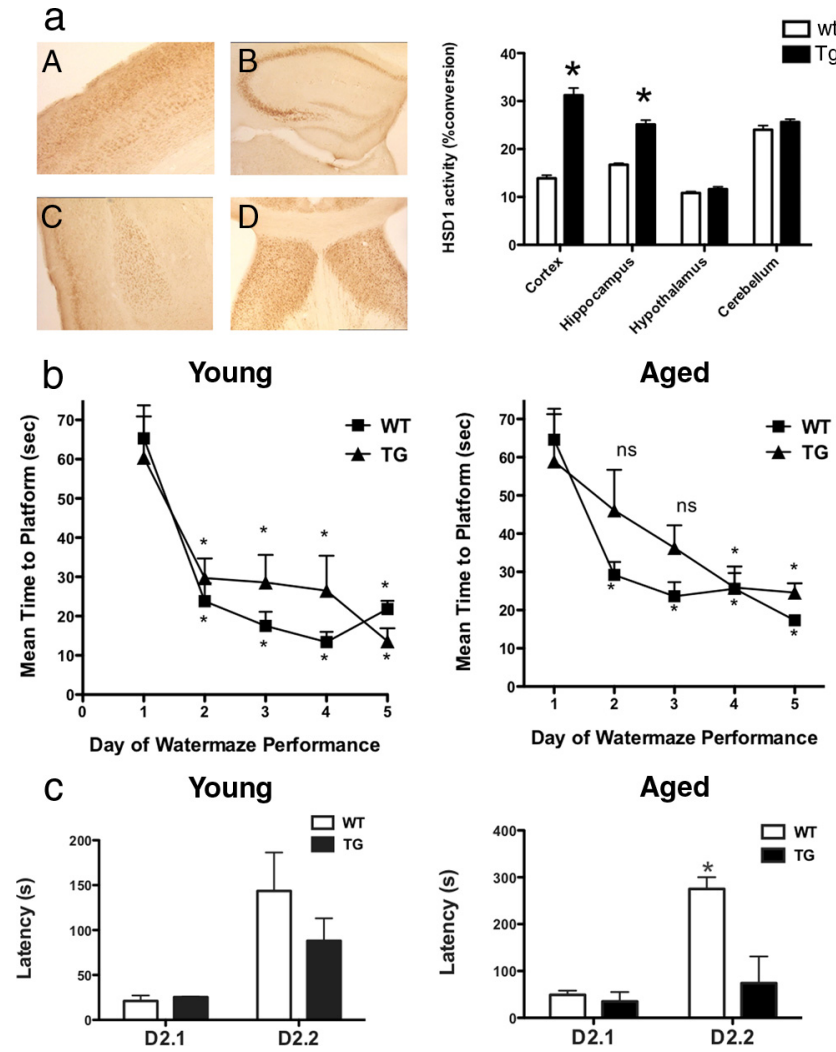

Figure 2. Forebrain overexpression of $11 \beta$-HSD1 causes cognitive decline with aging. $\boldsymbol{a}$, Left, Immunohistochemical localization of CamIIK-HSD1 transgene using HA-tag antibodies in cerebral cortex $(\boldsymbol{A})$, hippocampus $(\boldsymbol{B})$, amygdala $(\boldsymbol{C})$, and lateral septum $(\boldsymbol{D})$. Right, $11 \beta$-HSD1 activity (percentage conversion corticosterone-11-dehydrocorticosterone) was increased $\left({ }^{*} p<0.05\right)$ in cerebral cortex and hippocampus of CamlIK-HSD1 (Tg) mice compared with wt, $n=7$ per group. $\boldsymbol{b}$, Aging (18 months), but not young (6-9 months) ( $n=8 /$ group), Tg mice display delayed learning of water maze task compared with age-matched wt littermates; ${ }^{*} p<$ 0.05 , compared with respective day 1 value. $c$, Attenuated retention of conditioned behavior in aging $\mathrm{Tg}$ mice. Young and aging $\mathrm{Tg}$ and wt mice were tested for latency to move from light to dark compartments on day 2 shock trial (D2.1) and 5 h postshock (D2.2); ${ }^{*} p<0.05$ compared with D2.1 value.

5.2, $p<0.05$ ] (Fig. 1c), such that higher $11 \beta$-HSD1 mRNA associated with poorer learning and memory. Neither MR nor GR mRNA expression was altered with age in any hippocampal subregion (supplemental Fig.S1, available at www.jneurosci.org as supplemental material). In the parietal cortex, $11 \beta$-HSD 1 mRNA $11 \beta$-HSD1 mRNA expression was significantly higher in layer $\mathrm{V}$ of aged compared with young mice $\left[F_{(1,22)}=4.4, p<0.05\right]$ and correlated negatively with spatial learning [path lengths on day 5 : $\left.r=0.47, F_{(1,18)}=5.2, p<0.05\right)$ ] (Fig. $1 c$ ) but not spatial memory retention (probe test) $(p=0.3)$. Plasma corticosterone levels were significantly increased in aged C57BL/6J mice [young: $3.3 \pm$ $12.5 \mathrm{~nm}$; aged: $\left.147.2 \pm 18.8 \mathrm{nM}, F_{(1,22)}=6.9, p<0.05\right]$ but did not correlate with water maze performance (path length on day 5 : $p=0.6$; probe: $p=0.3$ ).

To determine whether the increased brain $11 \beta$-HSD1 causes learning and memory deficits, forebrain-specific CamIIK-HSD1 Tg mice (three lines) and wt littermates were generated. Tg mice exhibited transgene protein in the forebrain, notably in cortex and hippocampus, showing an increase in $11 \beta$-HSD1 activity of 125 and 50\% in these regions, respectively (Fig. $2 a$ ).

Young (6-9 months) Tg mice learned to find and escape onto the hidden water maze platform as well as wt (Fig. $2 b$ ) [genotype effect: $F_{(1,15)}=1.46, p=0.37$ ]. While old (18 months) Tg mice 
performed the cued version of the water maze as well as wt with comparable swim speeds (wt: $0.18 \pm 0.01 \mathrm{~m} / \mathrm{s}$; Tg: $0.18 \pm 0.02$ $\mathrm{m} / \mathrm{s}$ ), they were slower to learn the hidden platform location; specifically, wt mice, but not $\mathrm{Tg}$ mice, significantly improved between the first and second day of training $\left[F_{(1,14)}=3.8, p<\right.$ 0.01 ] (Fig. 2b).

In the conditioned passive avoidance test, young $\mathrm{Tg}$ and wt mice had similarly increased latencies to re-enter the dark compartment at $5 \mathrm{~h}$ re test following footshock [genotype effect: $F_{(1,14)}=0.29, p=0.08$ ] (Fig. $2 b$ ). While old wt mice responded with an increased latency to enter the dark compartment, old Tg mice failed to respond to this conditioning stimulus [genotype effect: $F_{(1,14)}=9.8, p=0.01$ ] (Fig. $2 c$ ). This impaired learning was not due to anxiety-related behaviors (supplemental Table S1, available at www.jneurosci.org as supplemental material) or to altered basal, circadian, or stress-induced glucocorticoid levels (supplemental Table S2, available at www.jneurosci.org as supplemental material), mirroring normal HPA axis function in $11 \beta$-HSD $1^{-1-}$ mice on this background (Yau et al., 2007).

\section{Discussion}

The key findings in this study are that $11 \beta$-HSD1 expression is increased in the hippocampus and cortex with aging in mice and that levels of $11 \beta$-HSD1 mRNA in CA3 and cortical layer V pyramidal cells correlate with cognitive function in the water maze. Modest transgenic overexpression of $11 \beta$-HSD1 in the forebrain produces accelerated cognitive dysfunction with aging, providing the first evidence that forebrain $11 \beta$-HSD1 levels alone are sufficient to alter cognitive behavior in aging mice, an effect not due to affective dysfunction or altered plasma glucocorticoid levels.

Increased $11 \beta$-HSD1 mRNA expression with age in C57BL/6J mice was confined to hippocampal CA3 and cortical layer V pyramidal cells; interestingly, both regions are particularly sensitive to age-related damage (Casu et al., 2002; Mueller et al., 2008). In CA3 specifically, excess glucocorticoids and chronic restraint stress cause dendritic atrophy, a structural deterioration that makes neurons more vulnerable to excitotoxins (Conrad et al., 2007) and impairs spatial memory (Luine et al., 1994; Conrad et al., 1996; Sunanda et al., 2000). Moreover, spatial memory in the water maze depends critically on the integrity of the hippocampal CA3 subfield (Steffenach et al., 2002) and on plasticity-related mRNA transcripts within the hippocampal CA3 subregion (Haberman et al., 2008). Parietal cortex is also involved in spatial learning (Save and Poucet, 2009).

While the selective increase in hippocampal $11 \beta$-HSD1 mRNA expression was modest (with no changes to MR or GR expression), two lines of evidence suggest this may be sufficient to influence hippocampal functional deficits with aging. First, $11 \beta$-HSD1 mRNA in CA3 cells correlated with age-associated cognitive function. Neither plasma corticosterone levels, which increased with age, nor the hippocampal MR and GR expression correlated with spatial learning and memory. Although correlation does not prove causation, modest transgenic overexpression of $11 \beta$-HSD1 in forebrain, including hippocampus, produced hippocampusassociated cognitive deficits in the water maze and inhibitory avoidance tasks. Indeed, in this model $11 \beta$-HSD1 expression is modified solely in the forebrain to generate an accelerated cognitive decline observed at a time when the wild-type controls have unimpaired cognition; this excludes the possibility that other factors modified in aging may be causal in generating this phenotype. Since we found no evidence for either of the elevated plasma corticosterone levels (diurnal or with stress) in the transgenic mice, we infer that the likely cause of the cognitive deficits is intraneuronal glucocorticoid excess, the reverse of the situation in $11 \beta$-HSD $1^{-1-}$ mice, but in this case clearly reflecting direct effects upon the CNS rather than effects secondary to the metabolic and neuroendocrine changes seen in generalized $11 \beta$-HSD1 knock-out mice (Kotelevtsev et al., 1997; Harris et al., 2001; Morton et al., 2001).

The mechanisms leading to elevated $11 \beta$-HSD1 in specific neurons are uncertain. However, the $11 \beta$-HSD 1 gene promoter is predominantly regulated directly by CCAAT/enhancer binding protein $(\mathrm{C} / \mathrm{EBP})$ transcription factors, with induction by $\mathrm{C} / \mathrm{EBP} \alpha$ and constraint by $\mathrm{C} / \mathrm{EBP} \beta$, at least in liver (Chapman and Seckl, 2008). $\mathrm{C} / \mathrm{EBP} \beta$ is also important for memory consolidation (Taubenfeld et al., 2001) and intriguingly shows deficient induction in the aging hippocampus (Monti et al., 2005).

The cognitive deficits were only manifest with aging in $\mathrm{Tg}$ mice, thus excluding developmental effects of the transgenic manipulation, which are also unlikely given that expression from the CAMIIK promoter occurs postnatally, when much brain development is complete. There may be several reasons why we did not observe cognitive deficits in young Tg mice: (1) intraneuronal corticosterone concentrations (via $11 \beta$-HSD1 action and free corticosterone from blood) may not be high enough in young $\mathrm{Tg}$ mice, with lower plasma corticosterone levels than aged mice, to have an impact on cognitive function; (2) small cognitive impairments may indeed exist in young $\mathrm{Tg}$ mice, but the tasks used were not sufficiently demanding for the detection of such changes; and (3) aging per se may be necessary for the emergence of deficits. Indeed, aged mice are more sensitive to stress-induced spatial memory impairments than young mice (Buchanan et al., 2008); the time-related accumulation of myriad deficits that underpin "allostatic load" through life may also be pertinent (McEwen, 2007), interacting with increased intracellular GC exposure to initiate premature cognitive deficits. Taken alongside the rise of $11 \beta$-HSD 1 in the hippocampus and layer V of the cortex of aged, cognitively impaired mice, these data suggest that cognitive decline with aging may reflect intraneuronal "Cushing's disease of the brain," tipping the balance from the beneficial adaptive effects of acute rises in glucocorticoids to the deleterious consequences of chronically elevated levels. This forms intriguing parallels with obesity and metabolic syndrome, which associate with excess $11 \beta$-HSD1 selectively in adipose tissue (Chapman and Seckl, 2008). The data also afford a rationale for developing $11 \beta$-HSD 1 inhibitors for therapy of age-related cognitive disorders (Webster et al., 2007). Indeed early proof-of-concept studies suggest efficacy in humans (Sandeep et al., 2004).

\section{References}

Buchanan JB, Sparkman NL, Chen J, Johnson RW (2008) Cognitive and neuroinflammatory consequences of mild repeated stress are exacerbated in aged mice. Psychoneuroendocrinology 33:755-765.

Casu MA, Wong TP, De Koninck Y, Ribeiro-da-Silva A, Cuello AC (2002) Aging causes a preferential loss of cholinergic innervation of characterized neocortical pyramidal neurons. Cereb Cortex 12:329-337.

Chapman KE, Seckl JR (2008) 11beta-HSD1, inflammation, metabolic disease and age-related cognitive (dys)function. Neurochem Res 33:624-636.

Conrad CD, Galea LA, Kuroda Y, McEwen BS (1996) Chronic stress impairs rat spatial memory on the $\mathrm{Y}$ maze, and this effect is blocked by tianeptine pretreatment. Behav Neurosci 110:1321-1334.

Conrad CD, McLaughlin KJ, Harman JS, Foltz C, Wieczorek L, Lightner E, Wright RL (2007) Chronic glucocorticoids increase hippocampal vulnerability to neurotoxicity under conditions that produce CA3 dendritic retraction but fail to impair spatial recognition memory. J Neurosci 27:8278-8285.

Haberman RP, Lee HJ, Colantuoni C, Koh MT, Gallagher M (2008) Rapid 
encoding of new information alters the profile of plasticity-related mRNA transcripts in the hippocampal CA3 region. Proc Natl Acad Sci U S A 105:10601-10606.

Harris HJ, Kotelevtsev Y, Mullins JJ, Seckl JR, Holmes MC (2001) Intracellular regeneration of glucocorticoids by $11 \beta$-hydroxysteroid dehydrogenase (11 $\beta$-HSD)-1 plays a key role in regulation of the HPA axis: analysis of $11 \beta$-HSD-1 deficient mice. Endocrinology 142:114-120.

Holmes MC, Seckl JR (2006) The role of 11beta-hydroxysteroid dehydrogenases in the brain. Mol Cell Endocrinol 248:9-14.

Holmes MC, Abrahamsen CT, French KL, Paterson JM, Mullins JJ, Seckl JR (2006) The mother or the fetus? $11 \beta$-Hydroxysteroid dehydrogenase type 2 null mice provide evidence for direct fetal programming of behavior by endogenous glucocorticoids. J Neurosci 26:3840-3844.

Kotelevtsev Y, Holmes MC, Burchell A, Houston PM, Schmoll D, Jamieson P, Best R, Brown R, Edwards CRW, Seckl JR, Mullins JJ (1997) 11 $\beta$ Hydroxysteroid dehydrogenase type 1 knockout mice show attenuated glucocorticoid-inducible responses and resist hyperglycemia on obesity or stress. Proc Natl Acad Sci U S A 94:14924-14929.

Landfield PW, Baskin RK, Pitler TA (1981) Brain aging correlates: retardation by hormonal-pharmacological treatments. Science 214:581-584.

Livingstone DE, Jones GC, Smith K, Jamieson PM, Andrew R, Kenyon CJ, Walker BR (2000) Understanding the role of glucocorticoids in obesity: tissue-specific alterations of corticosterone metabolism in obese Zucker rats. Endocrinology 141:560-563.

Luine V, Villegas M, Martinez C, McEwen BS (1994) Repeated stress causes reversible impairments of spatial memory performance. Brain Res 639:167-170.

Lupien SJ, de Leon M, de Santi S, Convit A, Tarshish C, Nair NPV, Thakur M, McEwen BS, Hauger RL, Meaney MJ (1998) Cortisol levels during human aging predict hippocampal atrophy and memory deficits. Nat Neurosci 1:69-73.

Masuzaki H, Paterson J, Shinyama H, Morton NM, Mullins JJ, Seckl JR, Flier JS (2001) A transgenic model of visceral obesity and the metabolic syndrome. Science 294:2166-2170.

Masuzaki H, Yamamoto H, Kenyon CJ, Elmquist JK, Morton NM, Paterson JM, Shinyama H, Sharp MG, Fleming S, Mullins JJ, Seckl JR, Flier JS (2003) Transgenic amplification of glucocorticoid action in adipose tissue causes high blood pressure in mice. J Clin Invest 112:83-90.

Mattsson C, Lai M, Noble J, McKinney E, Yau JL, Seckl JR, Walker BR (2003) Obese Zucker rats have reduced mineralocorticoid receptor and 11beta-hydroxysteroid dehydrogenase type 1 expression in hippocampusimplications for dysregulation of the hypothalamic-pituitary-adrenal axis in obesity. Endocrinology 144:2997-3003.

McEwen BS (2007) Physiology and neurobiology of stress and adaptation: central role of the brain. Physiol Rev 87:873-904.

McEwen BS, de Leon MJ, Lupien SJ, Meaney MJ (1999) Corticosteroids, the aging brain and cognition. Trends Endocrinol Metab 10:92-96.

Meaney MJ, Odonnell D, Rowe W, Tannenbaum B, Steverman A, Walker M, Nair NPV, Lupien S (1995) Individual differences in hypothalamicpituitary-adrenal activity in later life and hippocampal aging. Exp Gerontol 30:229-251.

Monti B, Berteotti C, Contestabile A (2005) Dysregulation of memoryrelated proteins in the hippocampus of aged rats and their relation with cognitive impairment. Hippocampus 15:1041-1049.

Morton NM, Holmes MC, Fievet C, Staels B, Tailleux A, Mullins JJ, Seckl JR (2001) Improved lipid and lipoprotein profile, hepatic insulin sensitivity, and glucose tolerance in 11beta-hydroxysteroid dehydrogenase type 1 null mice. J Biol Chem 276:41293-41300.
Mueller SG, Schuff N, Raptentsetsang S, Elman J, Weiner MW (2008) Selective effect of Apo e4 on CA3 and dentate in normal aging and Alzheimer's disease using high resolution MRI at $4 \mathrm{~T}$. Neuroimage 42:42-48.

Paterson JM, Morton NM, Fievet C, Kenyon CJ, Holmes MC, Staels B, Seckl JR, Mullins JJ (2004) Metabolic syndrome without obesity: hepatic overexpression of 11beta-hydroxysteroid dehydrogenase type 1 in transgenic mice. Proc Natl Acad Sci U S A 101:7088-7093.

Paterson JM, Holmes MC, Kenyon CJ, Carter R, Mullins JJ, Seckl JR (2007) Liver-selective transgene rescue of hypothalamic-pituitary-adrenal axis dysfunction in 11beta-hydroxysteroid dehydrogenase type 1-deficient mice. Endocrinology 148:961-966.

Rajan V, Edwards CRW, Seckl JR (1996) 11 $\beta$-Hydroxysteroid dehydrogenase in cultured hippocampal cells reactivates inert 11-dehydrocorticosterone, potentiating neurotoxicity. J Neurosci 16:65-70.

Rask E, Walker BR, Soderberg S, Livingstone DE, Eliasson M, Johnson O, Andrew R, Olsson T (2002) Tissue-specific changes in peripheral cortisol metabolism in obese women: increased adipose 11beta-hydroxysteroid dehydrogenase type 1 activity. J Clin Endocrinol Metab 87:3330-3336.

Sandeep TC, Yau JL, MacLullich AM, Noble J, Deary IJ, Walker BR, Seckl JR (2004) 11beta-Hydroxysteroid dehydrogenase inhibition improves cognitive function in healthy elderly men and type 2 diabetics. Proc Natl Acad Sci U S A 101:6734-6739.

Save E, Poucet B (2009) Role of the parietal cortex in long-term representation of spatial information in the rat. Neurobiol Learn Mem 91:172-178.

Steffenach HA, Sloviter RS, Moser EI, Moser MB (2002) Impaired retention of spatial memory after transection of longitudinally oriented axons of hippocampal CA3 pyramidal cells. Proc Natl Acad Sci U S A 99:31943198.

Stewart PM, Boulton A, Kumar S, Clark PM, Shackleton CH (1999) Cortisol metabolism in human obesity: impaired cortisone $\rightarrow$ cortisol conversion in subjects with central adiposity. J Clin Endocrinol Metab 84:1022-1027.

Sunanda, Rao BS, Raju TR (2000) Restraint stress-induced alterations in the levels of biogenic amines, amino acids, and AChE activity in the hippocampus. Neurochem Res 25:1547-1552.

Taubenfeld SM, Milekic MH, Monti B, Alberini CM (2001) The consolidation of new but not reactivated memory requires hippocampal C/EBPbeta. Nat Neurosci 4:813-818.

Wamil M, Seckl JR (2007) Inhibition of 11beta-hydroxysteroid dehydrogenase type 1 as a promising therapeutic target. Drug Discov Today 12: 504-520.

Webster SP, Ward P, Binnie M, Craigie E, McConnell KM, Sooy K, Vinter A Seckl JR, Walker BR (2007) Discovery and biological evaluation of adamantyl amide 11beta-HSD1 inhibitors. Bioorg Med Chem Lett 17:2838 2843.

Yau JL, Noble J, Kenyon CJ, Hibberd C, Kotelevtsev Y, Mullins JJ, Seckl JR (2001) Lack of tissue glucocorticoid reactivation in 11beta -hydroxysteroid dehydrogenase type 1 knockout mice ameliorates age-related learning impairments. Proc Natl Acad Sci U S A 98:4716-4721.

Yau JL, Noble J, Hibberd C, Rowe WB, Meaney MJ, Morris RG, Seckl JR (2002) Chronic treatment with the antidepressant amitriptyline prevents impairments in water maze learning in aging rats. J Neurosci 22:1436-1442.

Yau JL, McNair KM, Noble J, Brownstein D, Hibberd C, Morton N, Mullins JJ, Morris RG, Cobb S, Seckl JR (2007) Enhanced hippocampal longterm potentiation and spatial learning in aged 11beta-hydroxysteroid dehydrogenase type 1 knock-out mice. J Neurosci 27:10487-10496. 